\title{
PENGARUH COGNITIVE STYLE DAN GLOBAL MINDSET TERHADAP MANAJEMEN KEUANGAN PRIBADI DAN PENGARUH MANAJEMEN KEUANGAN PRIBADI TERHADAP INTENSI BERWIRAUSAHA
}

\author{
Peter Garlans Sina (petersina83@gmail.com) \\ Fakultas Ekonomi, UKSW-Salatiga
}

\begin{abstract}
The aim of this research was to give a proof that the factors of style of thinking, global mindset, and personal finance management are the predictors for the entrepreneurial intentions. Through the distribution of questioners for 150 respondents, the results show that style of thinking and global mindset gave significant effects on personal finance management and it was also gave significant effect on entrepreneurial intentions. In the final section, the limitation of the research was also discussed which can be a follow-up by other researchers.
\end{abstract}

Keywords: cognitive style, global mindset, personal finance, entrepreneurial intention

\section{PENDAHULUAN}

Salah satu langkah nyata agar lapangan kerja yang tersedia meningkat adalah dengan menciptakan para wirausahawan. Dengan lahirnya para wirausahawan ini diharapkan dengan satu orang wirausahawan dapat mempekerjakan minimal 2- 3 orang saja, pemerintah sudah sangat terbantu untuk mengurangi tingkat pengangguran di Indonesia. Bagi dunia pendidikan saat ini, banyak muncul program- program pendidikan kewirausahaan dengan tujuan untuk membekali peserta didiknya menjadi wirausahawan mandiri dan sukses (Sina \& Ida, 2012).

Untuk itu perlu adanya upaya yang serius untuk menciptakan benih-benih berwirausaha pada masyarakat Indonesia, namun pada kenyataannya tidaklah seperti yang diharapkan karena masih kurangnya niat untuk berwirausaha. Dalam perpsektif sain bahwa terdapat berbagai faktor yang turut menentukan keberhasilan menciptakan para wirausaha. Seperti yang ditemukan oleh Indarti dan Rostiani (2008) bahwa motivasi berprestasi, efikasi diri dan faktor demografi. Sarwoko (2011) tentang faktor norma subjektif dan efikasi diri, Sina dan Ida (2012) tentang faktor literasi keuangan dan cognitive style, serta peneliti lainnya.

Berpijak pada berbagai temuan sebelumnya diketahui bahwa ada beragam faktor yang menentukan terbentuknya niat berwirausaha. Untuk itu dalam penelitian ini akan mencoba mengembangkan dan mengintegrasi faktor-faktor lainnya seperti personal finance, global mindset dan cognitive style yang diduga turut menentukan niat berwirausaha. Oleh karena itu, masalah penelitian yang diangkat adalah bagaimana pengaruh global mindset dan cognitive style terhadap personal finance dan efeknya personal finance terhadap niat berwirausaha. Sedangkan tujuan penelitian adalah untuk mengetahui prediktor-prediktor dari niat berwirausaha.

\section{LANDASAN TEORI DAN PENGEMBANGAN HIPOTESIS}

\section{Cognitive style}

Allison dan Hayes (1996) menyatakan bahwa gaya kognitif intuitif lebih mengandalkan otak belahan kanan yang memiliki karakteristik intuitif, integratif, cara berpikir non-linier, 
pertimbangan berdasarkan perasaan, dan perspektif luas. Sedangkan gaya kognitif analitis lebih mengandalkan fungsi otak belahan kiri yang memiliki karakteristik kesadaran, analitikal, logikal, pemrosesan informasi sekuensial, pertimbangan berdasarkan penalaran, dan fokus pada detail. Sementara itu, Kahneman (2003) menegaskan bahwa gaya kognitif terbagi menjadi dua kategori yaitu sistem satu (intuition) dan sistem dua (reasoning). Sistem satu menggunakan intuisi dalam memproses informasi sedangkan sistem dua menggunakan penalaran.

Terkait bidang keuangan, asumsi keuangan konvesional menyatakan bahwa manusia memiliki kemampuan mengoptimalkan utilinya dan hal ini mengindikasikan keseragaman dalam cara berpikir. Namun seiring berjalannya waktu, para ahli mulai menemukan bahwa asumsi tersebut tidak relevan karena manusia memiliki gaya berpikirnya yang unik, terutama ketika membuat keputusan keuangan (Prochaska-Cue, 1993). Lanjut, ketika membuat keputusan keuangan, orang akan bertendensi berpikir analisis dan holistik. Berpikir analisis merupakan gaya berpikir yang mampu meningkatkan peluang tepat dalam mengelola keuangan sedangkan holistik adalah kebalikannya.

\section{Mindset Global}

Gupta dan Govindarajan (2002) yang membagi global mindset menjadi dua orientasi. Tepatnya global mindset menggambarkan kombinasi sikap terbuka dan kesadaran berbagai perbedaan budaya dan nilai. Sedangkan Paul (2000) mengartikan global mindset sebagai seperangkat gambaran mental dan asumsi yang digunakan oleh individu untuk terus belajar dari pengalaman. Oleh karena itu, menurutnya global mindset dapat digunakan dalam tataran organisasi maupun individu. Arti sebelumnya dipertegas lagi oleh Beamish, Killing, Lecraw, dan Morison (1994) dengan karkateristik dari orang yang memiliki global mindset yaitu diantaranya adalah kemampuan untuk mengembangkan dan menggunakan keahlian strategi global, kemampuan mengelola perubahan dan transisi, kemampuan bekerja sama dalam tim dan lain-lainnya.

Sementara itu, Hartono (2007) mengartikan global mindset sebagai kemampuan mengkombinasi kecepatan analisis fenomena dan ketepatan meresponnya. Berpijak pada definisi tersebut tampak bahwa global mindset merupakan suatu kemampuan yang dapat dipelajari, dibangun dan diberdayakan sehingga dapat menembus tataran organisasi maupun individu. Lanjut bahwa bermodalkan global mindset akan mengarahkan pada perilaku yang memiliki kepekaan akan perubahan dan ketidakpastian. Dan semua itu akan memicu kesadaran diri untuk mau berubah ketika berada dalam tantangan. Dengan demikian, dalam penelitian menggunakan definisi menurut Hartono (2007).

\section{Manajemen Keuangan Pribadi}

Horne (1997) dalam Kawulur (2009) mengartikan manajemen keuangan sebagai segala aktivitas yang berhubungan dengan perolehan pendanaan dan pengelolaan aktiva dengan beberapa tujuan menyeluruh. Gitman dalam Krishna, Rofaida, dan Sari (2010) bahwa manajemen keuangan merupakan proses perencanaan, analisa dan pengendalian kegiatan keuangan. Salah satu bentuk aplikasi dari manajemen keuangan adalah yang disebut manajemen keuangan pribadi yaitu proses perencanaan dan pengendalian keuangan dari unit individu atau keluarga. Keuangan pribadi meliputi manajemen uang (money management), pengeluaran dan kredit (spending and credit), dan tabungan dan investasi (saving and investing).

Sedangkan Parrota dan Johnson (1998) menyatakan bahwa manajemen keuangan pribadi dapat diartikan sebagai proses perencanaan, implementasi dan evaluasi keuangan yang dilakukan oleh unit individu ataupun keluarga. Dengan demikian, diharapkan individu ataupun rumah tangga akan mampu menciptakan kekayaan yang dibutuhkan untuk memenuhi kebutuhan saat ini maupun di masa yang akan datang. Oleh karena itu, dalam 
penelitian ini menggunakan pengertian manajemen keuangan pribadi menurut Parrota dan Johnson (1998) karena terindikasi sistematis dalam mengelola keuangan.

\section{Intensi Berwirausaha}

Wijaya (2007) yang menyatakan bahwa intensi wirausaha adalah keinginan/niat yang ada pada diri seseorang untuk melakukan suatu tindakan wirausaha. Tidak jauh berbeda, Katz dan Gartner (1988) sebagaimana dikutip Indira dan Soenhadji (2010) bahwa intensi kewirausahaan dapat diartikan sebagai proses pencarian informasi yang dapat digunakan untuk mencapai tujuan pembentukan suatu usaha.

Sementara itu, Indarti \& Rostiani (2010) mempertajam melalui penjelasan bahwa seseorang dengan intensi untuk memulai usaha akan memiliki kesiapan dan kemajuan yang lebih baik dalam usaha yang dijalankan dibandingkan seseorang tanpa intensi untuk memulai usaha. Masih dari sumber yang sama, dijelaskan juga bahwa intensi telah terbukti menjadi prediktor yang terbaik bagi perilaku kewirausahaan. Oleh karena itu, intensi dapat dijadikan sebagai pendekatan dasar yang masuk akal untuk memahami siapa-siapa yang akan menjadi wirausaha.

\section{Pengembangan Hipotesis}

\section{Cognitive style Terhadap Personal finance}

Perbedaan mengelola vang relatif diabaikan pada keuangan konvesional dan hal ini sudah mulai ditinggalkan seiring adanya temuan-temuan bahwa manusia tidak sama dalam mengeloa vang. Seperti Sina dan Ida (2012) yang meneliti tentang literasi keuangan juga membuktikan bahwa cara orang mengeolah informasi untuk membuat suatu keputusan bertendensi berbeda. Kerkmann (1998) yang melakukan penelitian kualitatif tentang tahaptahap perubahan perilaku terkait uang juga menemukan bahwa masing-masing orang dapat saja berbeda sehingga ada orang yang mampu berubah relatif lama dan ada juga yang perubahan perilakunya bersifat kontemporer, dan semua itu disebabkan gaya berpikir orang tidak mutlak sama.

Rettig dan Schulz (1991) memperkuat melalui penjelasannya bahwa pola pengelolaan keuangan orang memiliki perbedaan karena memiliki gaya berpikir yang berbeda. Ada yang bertipe holistik dan ada yang bertipe analisis, dan kedua tipe tersebut memiliki implikasi pembuatan keputusan keuangan yang berbeda. Seperti, tipe analisis akan bertendensi memiliki prioritas dan tujuan yang jelas serta adanya penyusunan rencana yang baik sedangkan gaya berpikir holistik merupakan kebalikannya.

Nofsinger dan Varma (2007) meneliti tentang gaya berpikir ketika membuat keputusan keuangan menemukan bahwa gaya berpikir analisis merupakan gaya berpikir yang mampu mereduksi mengalami kekeliruan membuat keputusan keuangan dibandingkan gaya berpikir intuitif karena lebih mampu mengolah informasi atau mempertimbangkan informasi yang relevan sebelum membuat keputusan keuangan. Sementara itu, Prochaska-Cue (1993) mempertajam dengan menyatakan bahwa tipe analisis akan bertendensi membuat suatu pencapaian keuangan yang lebih baik daripada holistik atau intuitif karena setiap keputusan keuangan akan dicermati dengan seksama sebelum memutuskan. Oleh karena itu, hipotesis pertama yang dirumuskan adalah sebagai berikut :

$\mathrm{HI}$ : cognitive style berpengaruh pada manajemen keuangan pribadi

\section{Global Mindset Terhadap Personal Finance}

Paul, Meyskens dan Robbins mengemukan bahwa global mindset berimplikasi pada daya saing karena manajer yang memiliki mindset global akan peka terhadap perbedaan norma dan tantangan khas suatu budaya. Hal ini tentu saja akan mendorong citra perusahaan 
karena dianggap mampu menyesuaikan diri dengan baik di lingkungan bisnis yang bervariasi budayanya. Yende (2010) juga mengemukakan hal serupa bahwa organisasi yang memiliki tenaga sumber daya manusia bermindset global bertendensi berkinerja bagus karena memiliki kepekaan terhadap lingkungan bisnis yang penuh persaingan.

Terlepas dari efek mindset global pada organisasi, Paul (2000) menegaskan pada tataran individual bahwa global mindset sebagai seperangkat gambaran mental dan asumsi yang digunakan oleh individu untuk terus belajar dari pengalaman. Oleh karena itu, menurutnya global mindset dapat digunakan dalam tataran organisasi maupun individu. Beamish, et al (1994) menspesifikkan lagi bahwa orang yang memiliki global mindset yaitu diantaranya adalah kemampuan untuk mengembangkan dan menggunakan keahlian strategi global, kemampuan mengelola perubahan dan transisi, kemampuan bekerja sama dalam tim dan lain-lainnya.

Sehubungan dengan pengelolaan keuangan, dapat di jelaskan oleh Institute for SocioFinancial Studies (2000), meledaknya situs internet, majalah keuangan dan investasi serta media-media lainnya, mengakibatkan informasi cepat beredar ke masyarakat. Beberapa tahun lalu orang-orang kekurangan informasi. Saat ini, dibanjiri informasi, tetapi yang ironisnya adalah apakah orang-orang tersebut telah memiliki fondasi dalam dasar-dasar keuangan yang akan mengarahkan masyarakat untuk menggunakan informasi-informasi tersebut.

Untuk menjawabnya, dalam penelitian menduga bahwa orang yang memiliki mindset global bertendensi mampu memilah dan mengolah informasi yang tepat sebelum membuat keputusan keuangan. Dengan kata lain, setiap keputusan keuangan membutuhkan informasi sebagai dasar pembuatan sehingga memiliki mindset global yang merupakan kemampuan menganalisis dan merespon dengan tepat akan sangat membantu untuk mengolah informasi keuangan yang tepat sasaran. Oleh karena itu, rumusan hipotesisnya sebagai berikut :

H2 : mindset global berpengaruh pada manajemen keuangan pribadi

\section{Personal Finance Terhadap Niat Berwirausaha}

Temuan Oseifuah (2010) bahwa literasi keuangan berdampak pada perilaku berwirausaha sehingga perlu meningkatkan literasi keuangan. Nalarnya adalah literasi keuangan akan meningkatkan perilaku yang berdasarkan pengetahuan. Spesifiknya yaitu enterpreneur akan memahami tentang bagaimana strategisnya menggunakan sumber daya uang eksternal (debt) serta bagaimana melakukan investasi untuk ekspansi usaha. Sina dan Ida (2012) mempertegas juga dengan temuannya bahwa memiliki kemampuan mengolah keuangan yang tepat berefek pada munculnya niat berwirausaha. Dengan kata lain, manajemen kevangan priadi (personal finance) yang tinggi karena mmeiliki literasi kevangan yang tinggi dapat mendorong munculnya niat berwirausaha.

Kotzè dan Smit (2008) mempertegas lagi dengan temuannya bahwa manajemen keuangan pribadi dapat memicu niat berwirausaha karena adanya faktor tabungan dan juga investasi. Nalarnya adalah ketika orang mampu mengolah kevangan pribadinya dengan tepat yang terindikasi dalam keteraturan menabung untuk berinvestasi akan memudahkan untuk berwirausaha karena adanya modal usaha dan juga dapat terhindar dari perangkap utang. Semakin baik menghindari dari perangkap utang akan semakin bagus dalam mengakumulasi modal usaha. Oleh karena itu, menurut kedua peneliti bahwa perlu adanya upaya serius untuk meningkatkan kemampuan mengolah uang (personal finance) sehingga akumulasi modal usaha menjadi lebih mudah. Bermodalkan akumulasi modal usaha akan mendorong niat untuk mengakumulasi uang melalui kegiatan berwirausaha. Untuk itu, rumusan hipotesis yang dibangun adalah :

H3 : personal finance berpengaruh pada intensi berwirausaha 


\section{METODE PENELITIAN}

\section{Jenis Penelitian dan Jenis Data}

Jenis penelitian yang digunakan dalam penelitian ini adalah riset asosiatif yang bertujuan untuk mengetahui hubungan atau pengaruh antara dua variabel atau lebih. Riset ini bertujuan mengetahui pengaruh antar variabel yang disebut riset kausal (Supramono \& Utami 2004). Sedangkan jenis data yang digunakan dalam penelitian ini dibagi dalam dua jenis yaitu data primer dan data sekunder. Data primer diperoleh melalui survey, dengan cara menyebarkan kuesioner secara langsung kepada mahasiswa jurusan bahasa inggris UKAW-Kupang.

\section{Teknik Pengumpulan Data}

Teknik pengumpulan data yang digunakan dalam penelitian ini adalah survei. Menurut Supramono dan Utami (2004). Dalam penelitian ini, peneliti memberikan pertanyaan untuk variabel independen (cognitiver style, global mindset, personal finance) yang terdiri dari 26 pertanyaan untuk variabel cognitiver style, 16 pertanyaan untuk global mindset, dan pertanyaan untuk variabel personal finance sejumlah 17 pertanyaan. Sedangkan variabel dependennya adalah intensi berwirausaha yang terdiri dari 12 pertanyaan.

\section{Definisi Operasional Variabel}

Variabel Cognitive Style merupakan variabel Independen, yaitu variabel yang mempengaruhi atau menjadi penyebab besar kecilnya variabel lain. Masing-masing dimensi diukur dengan skala Likert dengan skala 5 poin: (1) Sangat Tidak Setuju, (2) Tidak Setuju, (3) Cukup Setuju, (4), Setuju (5) Sangat Setuju. Hal yang sama juga pada variabel Global mindset dan Variabel Personal Fiannce yang merupakan variabel Independen, yaitu variabel yang mempengaruhi atau menjadi penyebab besar kecilnya variabel lain. Variabel Intensi Berwirausaha merupakan variabel dependen, yaitu variabel yang variasinya dipengaruhi oleh variasi variabel bebas.

Tabel 1

Definisi Operasionalisasi Variabel

\begin{tabular}{|c|c|c|}
\hline Variabel & Definisi & Indikator \\
\hline $\begin{array}{c}\text { Cognitive } \\
\text { Style }\end{array}$ & $\begin{array}{l}\text { Dimensi psikologis yang } \\
\text { merepresentasi } \\
\text { konsistensi individual } \\
\text { dalam mengumpulkan } \\
\text { dan memproses } \\
\text { informasi (Nasution \& } \\
\text { Supriyadi 2007) }\end{array}$ & $\begin{array}{l}\text { 1. Pengalaman saya, berpikir rasional merupakan cara } \\
\text { yang paling realistis untuk membuat keputusan } \\
\text { 2. Untuk memecahkan masalah, saya harus mempelajari } \\
\text { setiap bagian secara mendetail. } \\
\text { 3. Paling efektif ketika pekerjaan saya meliputi suatu yang } \\
\text { jelas untuk dikerjakan. } \\
\text { 4. Saya mengalami kesulitan ketika bekerja dengan orang } \\
\text { yang langsung melihat hasil akhir tanpa } \\
\text { mempertimbangkan keseluruhan aspek-aspek dari } \\
\text { masalah. } \\
\text { 5. Saya menghindari mengambil tindakan jika hasil } \\
\text { bertentangan dengan peluang kesuksesan. } \\
\text { 6. Saya cenderung mengamati laporan daripada } \\
\text { membacanya secara mendetail. } \\
\text { 7. Pemahaman saya terhadap masalah cenderung } \\
\text { berasal dari pemikiran analisis daripada kilasan intuisi } \\
\text { 8. Saya tetap berusaha untuk teratur dalam pekerjaan } \\
\text { saya. } \\
\text { 9. Jenis pekerjaan yang paling saya sukai adalah } \\
\text { pekerjaan yang menuntut pendekatan logika. }\end{array}$ \\
\hline
\end{tabular}




\begin{tabular}{|c|c|c|}
\hline & & $\begin{array}{l}\text { 10. Saya jarang sekali membuat keputusan tanpa } \\
\text { pertimbangan akal saya. } \\
\text { 11. Diberikan cukup waktu, saya } \\
\text { mempertimbangkan setiap situasi secara jelas. } \\
\text { 12. Untuk dapat sukses dalam pekerjaan. Saya } \\
\text { menemukan bahwa penting untuk tidak melukai } \\
\text { perasaan orang lain. } \\
\text { 13. Cara terbaik bagi saya untuk memahami masalah } \\
\text { yaitu dengan memecahkannya menjadi bagian - } \\
\text { bagian yang kecil untuk dianalisis. } \\
\text { 14. Saya menemukan bahwa mengadopsi pendekatan } \\
\text { analisis untuk membuat keputusan akan menghabiskan } \\
\text { banyak waktu. } \\
\text { 15. Saya mengalami kemajuan ketika saya mengkalkulasi } \\
\text { risiko. } \\
\text { 16. Saya tahu bahwa mungkin saya suka untuk sangat } \\
\text { terorganisasi ketika mengerjakan suatu tugas. } \\
\text { 17. Saya selalu memperhatikan secara detail sebelum } \\
\text { saya membuat keputusan. } \\
\text { 18. Saya membuat banyak keputusan berdasarkan intuisi. } \\
\text { 19. Filosofiku adalah lebih baik untuk aman daripada } \\
\text { harus mengambil risiko. } \\
\text { 20. Ketika membuat keputusan. Saya membutuhkan } \\
\text { banyak waktu dan mempertimbangkan secara } \\
\text { menyeluruh semua faktor yang relevan. } \\
\text { 21. Saya lebih menyukai sesuatu yang tidak dapat } \\
\text { diprediksi daripada sesuatu yang dapat diprediksi. } \\
\text { 22. Kebanyakan orang memanggil saya sebagai pemikir } \\
\text { logis. } \\
\text { 23. Untuk benar-benar memahami fakta, saya } \\
\text { membutuhkan teori. } \\
\text { 24. Saya bekerja sangat baik dengan orang-orang yang } \\
\text { spontan. } \\
\text { sika saya menemukan penjelasan mendetail, maka } \\
\text { 26. Pendekatan saya untuk memecahkan masalah } \\
\text { adalah fokus pada bagian per bagian. } \\
\text { 25a menemukan kepuasan kerja. }\end{array}$ \\
\hline $\begin{array}{l}\text { Global } \\
\text { mindset }\end{array}$ & $\begin{array}{lr}\text { Kemampuan } & \\
\text { mengkombinasi } \\
\text { kecepatan analisis } \\
\text { fenomena } & \text { dan } \\
\text { ketepatan } & \text { untuk } \\
\text { meresponnya } & \text { (Hartono, } \\
2007) . & \end{array}$ & 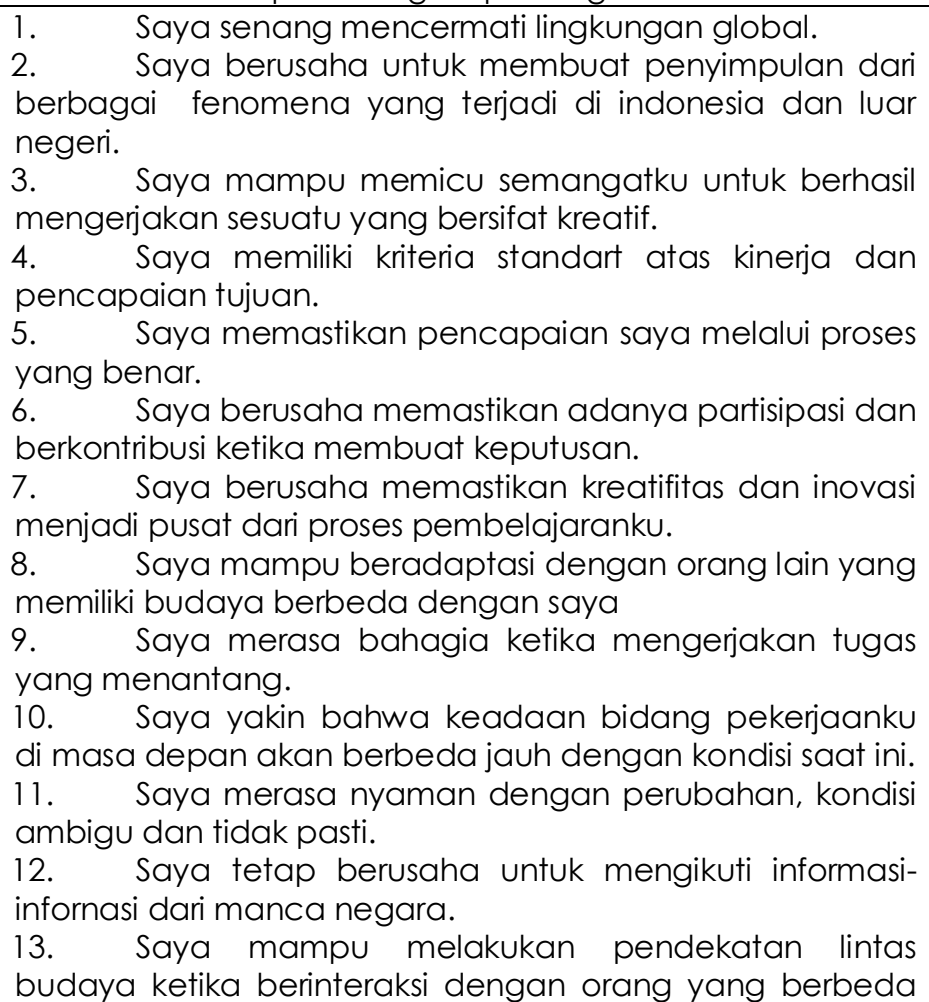 \\
\hline
\end{tabular}




\begin{tabular}{|c|c|c|}
\hline & & $\begin{array}{l}\text { budaya dengan saya. } \\
\text { 14. Saya berusaha untuk membaca buku-buku } \\
\text { penerbit dalam negeri dan manca negara. } \\
15 . \quad \text { Saya mampu membedah dan menyimpulkan } \\
\text { informasi yang terjadi di manca negara. } \\
\text { 16. Saya senang belajar. }\end{array}$ \\
\hline $\begin{array}{l}\text { Personal } \\
\text { finance }\end{array}$ & $\begin{array}{l}\text { Proses perencanaan, } \\
\text { implementasi dan } \\
\text { evaluasi keuangan yang } \\
\text { dilakukan oleh unit } \\
\text { individu ataupun } \\
\text { keluarga (Parrota \& } \\
\text { Johnson, 1998). }\end{array}$ & $\begin{array}{l}\text { 1. Ketika saya melihat sesuatu dan saya menginginkan. } \\
\text { Saya tidak akan tergesa-gesa untuk membelinya. } \\
\text { 2. Saya suka membeli barang yang saya butuhkan. } \\
\text { 3. Saya cenderung berbelanja lebih terarah ketika saya } \\
\text { mengetahui bahwa keuangan saya hampir lebihi batas } \\
\text { kemampuan untuk membeli. } \\
\text { 4. Saya mengahabiskan banyak uang daripada } \\
\text { kemampuan saya untuk membelinya. } \\
\text { 5. Ketika saya pergi ke tempat berbelanja. Saya hanya } \\
\text { membeli barang-barang yang saya butuhkan. } \\
\text { 6. Saya cenderung menghemat uang yang baru saja } \\
\text { saya peroleh. } \\
\text { 7. Saya bekerja keras untuk menghasilkan uang. } \\
\text { 8. Saya akan mencurahkan tenaga untuk menghasilkan } \\
\text { 9. Saya bekerja keras seumur hidup untuk meningkatkan } \\
\text { kekayaan saya. } \\
\text { 10. Saya antusias ketika tiba waktunya } \\
\text { mengahsilkan uang. } \\
\text { 11. Saya berusaha menyeimbangkan pengeluaran dan } \\
\text { penerimaan saya. } \\
\text { 12. Saya relatif baik untuk mengorganisasikan keuangan } \\
\text { saya. } \\
\text { 13. Saya banyak melakukan kesalahan ketika mengelola } \\
\text { uang saya. } \\
\text { 14. Saya melakukan investasi untuk jangka panjang. } \\
\text { 15. Saya menabung secara regular atau teratur. } \\
\text { 16. Saya menabung uang untuk masa depan keuangan } \\
\text { saya. } \\
\text { 17. Saya menyiapkan uang untuk kebutuhan tidak } \\
\text { terduga di masa mendatang. }\end{array}$ \\
\hline $\begin{array}{c}\text { Intensi } \\
\text { Berwiraus } \\
\text { aha }\end{array}$ & $\begin{array}{l}\text { Keinginan/niat yang } \\
\text { ada pada diri seseorang } \\
\text { untuk melakukan suatu } \\
\text { tindakan } \quad \text { wirausaha } \\
\text { (Wijaya 2007) }\end{array}$ & $\begin{array}{l}\text { 1. Saya akan memilih karir sebagai seorang } \\
\text { wirausahawan. } \\
\text { 2. Saya akan memilih karir sebagai karyawan dalam suatu } \\
\text { perusahaan/organisasi } \\
\text { 3. Saya lebih suka menjadi wirausahawan daripada } \\
\text { menjadi karyawan di suatu perusahaan/organisasi } \\
\text { 4. Saya mempersiapkan diri dengan sebaik-baiknya untuk } \\
\text { menjadi entrepreneur. } \\
\text { 5. Saya akan tetap berusaha untuk mengembangkan } \\
\text { usaha saya. } \\
\text { 6. Saya telah berpikir secara serius untuk memulai usaha } \\
\text { saya sendiri setelah lulus kuliah. } \\
\text { 7. Saya memiliki intensi yang tinggi untuk memulai usaha } \\
\text { kelak. } \\
\text { 8. Saya akan memulai usaha bisnis } 8 \text { tahun dari sekarang. } \\
\text { 9. Saya mau menjadi bos bagi saya sendiri. } \\
\text { 10. Saya memiliki niat untuk menghasilkan banyak uang } \\
\text { dari kegiatan bisnis } \\
\text { 11. Saya mampu mengembangkan produk-produk baru. } \\
\text { 12. Saya seringkali menghasilkan ide-ide baru. }\end{array}$ \\
\hline
\end{tabular}

Sumber: Indarti\& Rostiani (2010); 


\section{Populasi dan Sampel}

Populasi dalam penelitian ini adalah mahasiswa fakultas keguruan bahasa inggris UKAWKupang. Metode pengambilan sampel dalam penelitian ini adalah convenience sampling. Convenience sampling adalah metode pengambilan sampel dengan mengambil sampel secara bebas sesuai dengan kehendak penelitinya. Menggunakan rumus dari Yamane (1974) sebagaimana dikutip Supramono dan Utami (2004) diperoleh sebesar 92 responden dengan populasi sejumlah 1210 orang, namun untuk menjaga ada kuesioner yang tidak dikembalikan ditambah 60 responden sehingga sejumlah 152 kuesioner yang disebar.

\section{Pengujian Instrumen Penelitian}

Uji validitas instrumen penelitian adalah tingkat kemampuan instrumen penelitian untuk mengungkapkan data sesuai dengan masalah yang hendak diungkapkannya. Validitas pengukuran berhubungan dengan kesesuaian dan kecermatan fungsi ukur dari alat yang digunakan. Uji reliabilitas merupakan tingkat kebebasan dari random errors sehingga alat ukur yang digunakan dapat memberi hasil yang konsisten. Jadi, reliabilitas menyangkut akurasi konsistensi, dan stabilitas alat ukur. Suatu kuesioner dikatakan handal jika jawaban seseorang terhadap pernyataan adalah konsisten atau stabil dari waktu ke waktu (Ghozali, 2001: 129).

Terkait tahapan analisis, penelitian ini melibatkan 150 responden yang merupakan mahasiswa FKIP Bahasa Inggris UKAW Kupang karena 2 kuesioner tidak memenuhi kelayakan dianalisis lebih lanjut. Dari sampel tersebut, diperoleh responden yang berjenis kelamin perempuan sejumlah $66 \%$ dan yang berjenis kelamin laki-laki sejumlah $34 \%$. Dengan demikian, responden yang dominan adalah responden berjenis kelamin perempuan. Sedangkan responden berdasarkan usia diperoleh hasil yaitu $2 \%$ antara usia 16 hingga 17 tahun dan $32 \%$ antara usia 18 hingga 19 tahun. 32\% untuk usia 20 hingga 21 tahun. $26 \%$ untuk usia 21 hingga 22 tahun dan $8 \%$ untuk usia di atas 22 tahun. Dengan demikian, responden dalam penelitian ini dominan berada usia 18 hingga 21 tahun.

Terkait pengukuran validitas gaya berpikir diperoleh hasil bahwa 13 item pertanyaan dari 26 item pertanyaan memiliki nilai dibawah 0,30. Item pertanyaan mindset global 3 item pertanyaan dari 15 item pertanyaan memiliki nilai dibawah 0,30, dan untuk manajemen keuangan pribadi 4 item pertanyaan dari 17 item pertanyaan memiliki nilai dibawah 0,30 sedangkan intensi berwirausaha semua item pertanyaan valid. Untuk hasil pengukuran reliabilitas setelah mengeliminasi pertanyaan, diperoleh nilai alpha cronbach gaya berpikir sebesar 0, 691. Untuk mindset global sebesar 0,800, untuk manajemen keuangan pribadi sebesar 0,779 dan yang terakhir intensi berwirausaha sebesar 0,790. Dengan demikian analisis dilanjutkan pada tahapan selanjutnya yakni analisis deskriptif. 
Tabel 2

Distribusi Responden

\begin{tabular}{|c|c|c|c|c|}
\hline Panel & Kategori & Interval & $\mathbf{N}$ & $\%$ \\
\hline \multirow[t]{5}{*}{ A. Gaya Berpikir } & $1-1.81$ & Sangat Rendah & 0 & \\
\hline & $1.82-2.6$ & Rendah & 0 & \\
\hline & $2.61-3.4$ & Cukup Tinggi & 20 & $13 \%$ \\
\hline & $3.41-4.2$ & Tinggi & 91 & $61 \%$ \\
\hline & $3.21-5$ & Sangat Tinggi & 39 & $26 \%$ \\
\hline \multirow[t]{5}{*}{ B. Global Mindset } & $1-1.81$ & Sangat Rendah & 0 & \\
\hline & $1.82-2.6$ & Rendah & 2 & $1 \%$ \\
\hline & $2.61-3.4$ & Cukup Tinggi & 19 & $13 \%$ \\
\hline & $3.41-4.2$ & Tinggi & 104 & $69 \%$ \\
\hline & $3.21-5$ & Sangat Tinggi & 25 & $17 \%$ \\
\hline \multirow{5}{*}{$\begin{array}{l}\text { C. Manajemen Keuangan } \\
\text { Pribadi }\end{array}$} & $1-1.81$ & Sangat Rendah & 0 & \\
\hline & $1.82-2.6$ & Rendah & 5 & $3 \%$ \\
\hline & $2.61-3.4$ & Cukup Tinggi & 29 & $19 \%$ \\
\hline & $3.41-4.2$ & Tinggi & 85 & $57 \%$ \\
\hline & $3.21-5$ & Sangat Tinggi & 31 & $21 \%$ \\
\hline \multirow{5}{*}{$\begin{array}{l}\text { D. Intensi } \\
\text { Berwirausaha }\end{array}$} & $1-1.81$ & Sangat Rendah & 2 & $1 \%$ \\
\hline & $1.82-2.6$ & Rendah & 5 & $3 \%$ \\
\hline & $2.61-3.4$ & Cukup Tinggi & 47 & $31 \%$ \\
\hline & $3.41-4.2$ & Tinggi & 83 & $55 \%$ \\
\hline & $3.21-5$ & Sangat Tinggi & 13 & $9 \%$ \\
\hline
\end{tabular}

Merujuk pada tabel di atas, tampak bahwa mahasiswa FKIP Bahasa Inggris UKAW Kupang memiliki gaya berpikir dominan pada gaya berpikir analisis. Tidak jauh berbeda untuk mindset global yang berada dari cukup tinggi menuju sangat tinggi sehingga dapat dikatakan bahwa responden dominan memiliki mindset global yang tinggi. Hal yang sama juga pada manajemen keuangan pribadi dan intensi berwirasuaha yakni dari sedang menuju tinggi. Dengan demikian, responde yang digunakan dominan berada level sedang menuju tinggi. Setelah analisis deskriptif, langkah selanjutnya melakukan pengujian asumsi klasik seperti dibawah ini.

Tabel 3

Hasil Uji Multikolinieritas

\begin{tabular}{|c|c|c|c|c|c|c|c|c|}
\hline \multirow{2}{*}{\multicolumn{2}{|c|}{ Model }} & \multicolumn{2}{|c|}{$\begin{array}{l}\text { Unstandardized } \\
\text { Coefficients }\end{array}$} & \multirow{2}{*}{$\begin{array}{c}\text { Standardized } \\
\text { Coefficients } \\
\text { Beta }\end{array}$} & \multirow[b]{2}{*}{ T } & \multirow[b]{2}{*}{ Sig. } & \multicolumn{2}{|c|}{$\begin{array}{l}\text { Collinearity } \\
\text { Statistics }\end{array}$} \\
\hline & & B & $\begin{array}{l}\text { Std. } \\
\text { Error }\end{array}$ & & & & Tolerance & VIF \\
\hline \multirow[t]{3}{*}{1} & (Constant) & 13,413 & 4,735 & & 2,833 & .005 & & \\
\hline & CS & 148 & 087 & 131 & 1,706 & ,090 & 847 & 1,181 \\
\hline & GM & ,523 & 090 & 447 & 5,802 & 000 & 847 & 1,181 \\
\hline \multirow[t]{2}{*}{2} & (Constant) & 16,871 & 3,279 & & 5,146 & ,000 & & \\
\hline & $\mathrm{PF}$ & 561 & 072 & 537 & 7,752 & 000 & 1,000 & 1,000 \\
\hline
\end{tabular}

Kalkulasi pada Tabel 3 di atas menunjukkan bahwa nilai tolerance kurang dari $10 \%$ yang berarti tidak ada korelasi antar variabel bebas yang nilainya lebih dari $95 \%$. Dengan demikian, analisis dilanjutkan pada uji asumsi klasik lainnya yaitu uji heterokedastisitas. 

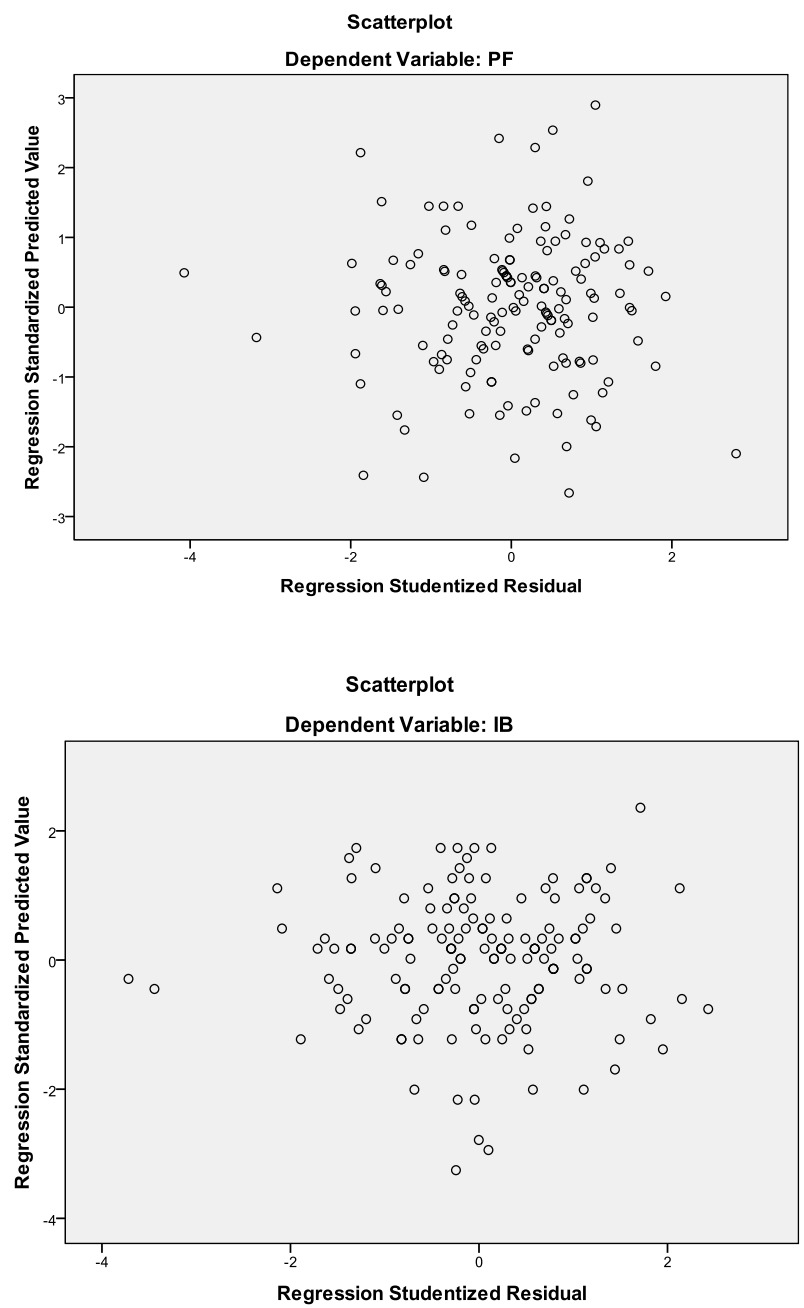

Grafik 1

Hasil Uji Heterokedastisitas

Mengacu pada Grafik 1 di atas diketahui bahwa tidak terjadi masalah heterokedastisitas karena data tersebar secara acak. Dengan kata lain yaitu apabila dilihat dari uji heterokedastisitas dengan menggunakan pendekatan analisis grafik scatterplot, dalam penelitian ini tidak terjadi masalah heterokedastisitas disebabkan data tersebar secara acak. 

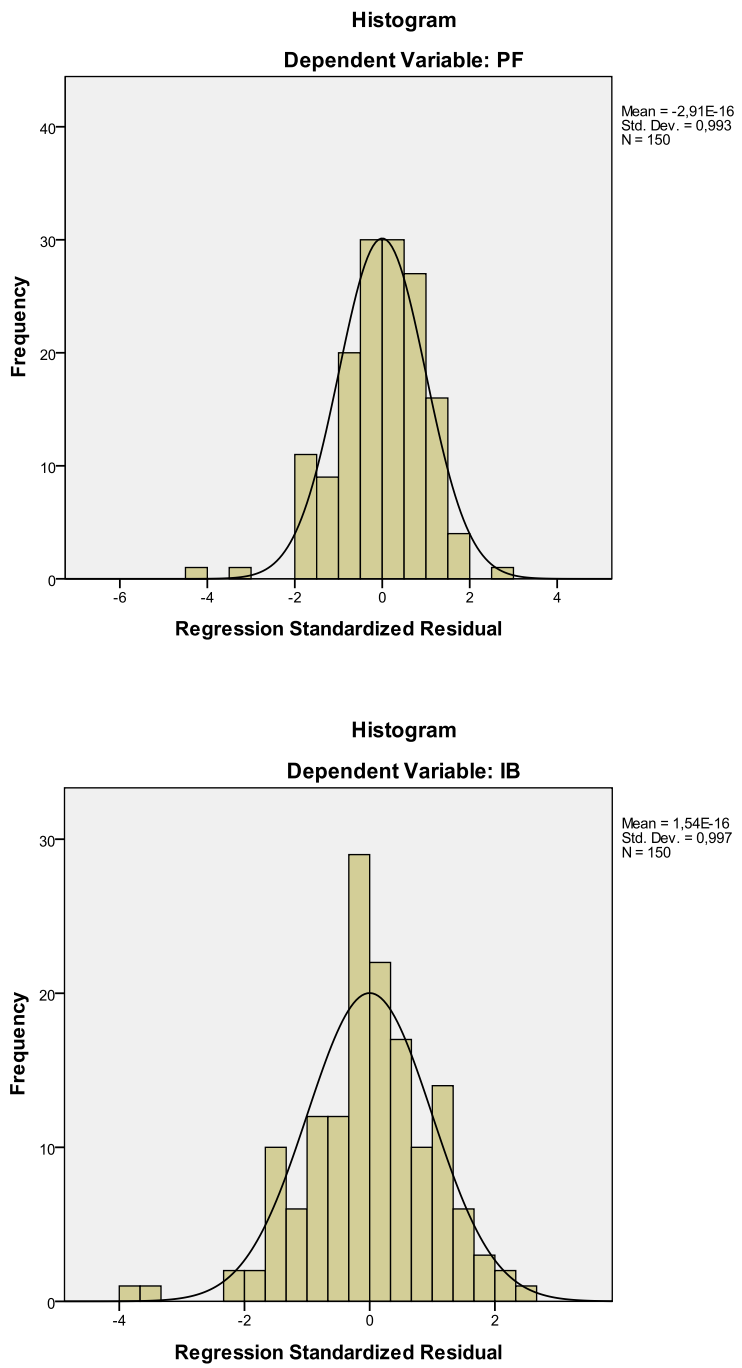

Grafik 2

Hasil Uji Normalitas

Berdasarkan Grafik 2 di atas, tampak bahwa data membentuk genta dan berarti data telah terdistribusi normal. Dan analisis pun dilanjutkan pada uji asumsi klasik terakhir yaitu uji linieritas.

Tabel 4

Hasil Uji Linieritas

\begin{tabular}{|l|l|r|r|r|r|r|}
\hline \multicolumn{2}{|l|}{ Model } & Sum of Squares & \multicolumn{1}{c|}{ df } & Mean Square & F & \multicolumn{1}{c|}{ Sig. } \\
\hline \multirow{3}{*}{1} & Regression & 1609,903 & 2 & 804,951 & 26,175 &, 000 \\
\cline { 2 - 7 } & Residual & 4520,691 & 147 & 30,753 & & \\
\cline { 2 - 7 } & Total & 6130,593 & 149 & & & \\
\hline 2 & Regression & 1927,599 & 1 & 1927,599 & 60,095 &, 000 \\
\cline { 2 - 7 } & Residual & 4747,235 & 148 & 32,076 & & \\
\cline { 2 - 7 } & Total & 6674,833 & 149 & & & \\
\hline
\end{tabular}

Merujuk Tabel 4, nilai sig yang diperoleh sebesar 0.000 dan lebih kecil dari 0.05 sehingga dapat dikatakan bahwa model yang dibangun telah linier. Setelah melakukan uji asumsi 
klasik dan dari keempat pengujian telah memenuhi kelayakan sehingga tahapan selanjutnya adalah melakukan pengujian hipotesis menggunakan regresi berganda.

Tabel 5

Hasil Uji Hipotesis

\begin{tabular}{|l|l|l|l|l|}
\hline \multicolumn{1}{|c|}{ Variabel } & \multicolumn{1}{|c|}{ B } & \multicolumn{1}{c|}{ t } & \multicolumn{1}{c|}{ sig } & R Square \\
\hline Gaya Berpikir &, 344 & 3,913 &, 000 & 0,094 \\
\hline Global Mindset &, 583 & 6,986 &, 000 & 0,248 \\
\hline Manajemen Kevangan Pribadi &, 561 & 7,752 &, 000 & 0,289 \\
\hline
\end{tabular}

Tabel 5 di atas menunjukkan nilai sig gaya berpikir sebesar 0,000 yang menunjukkan diterimanya $\mathrm{Hl}$. Hal ini berarti bahwa ada pengaruh antara gaya berpikir terhadap manajemen keuangan pribadi. Variabel kedua yaitu global mindset diperoleh nilai sig sebesar 0,000 dan berarti $\mathrm{H}_{2}$ diterima. Penerimaan hipotesis kedua berarti ada pengaruh antara mindset global terhadap manajemen keuangan pribadi. Kejadian yang sama juga pada hipotesis ketiga yakni manajemen keuangan pribadi berpengaruh pada intensi berwirausaha.

Diterimanya ketiga hipotesis menunjukkan bahwa keseluruhan hipotesis dalam penelitian ini diterima. Lanjut bahwa dilihat dari hasil analisis diketahui R Square sebesar 0, 094 bagi gaya berpikir dan sisanya dipengaruhi oleh faktor lainnya. Untuk mindset global sebesar 0,248 dan untuk manajemen keuangan pribadi sebesar 0,289. Dengan demikian, mengacu pada nilai R Square ketiga variabel independen diketahui bahwa manajemen keuangan pribadi yang memiliki pengaruh terbesar pada intensi berwirasuaha.

Setelah dilakukan analisis, tahapan selanjutnya adalah tahapan pembahasan. Diterimanya hipotesis pertama menandakan bahwa gaya berpikir, khususnya tipe analisis berpengaruh terhadap ketepatan mengelola keuangan pribadi. Oleh karena itu, semakin bagus analisis yang dilakukan maka semakin bagus pula seni mengelola keuangan pribadi. Hasil pada hipotesis pertama ini mendukung temuannya Nofsinger dan Varma (2007). Indikasi lainnya dari penerimaan hipotesis pertama yakni keyakinan bahwa semakin bagus dalam akumulasi pengalamana berpikir logis akan sangat mempertajam seni mengelola kevangan pribadi.

Lanjut bahwa mengapa berpikir logis akan membantu kemampuan mengelola keuangan pribadi karena kemampuan tersebut akan memudahkan dalam mengelola berbagai informasi keuangan yang dibuthkan guna membuat keputusan keuangan yang tepat sasaran. Selain itu juga, akan memudahkan dalam memilah informasi yang relevan dan yang tidak relevan sehingga ketika membuat pertimbangan untuk keputusan keuangan akan mereduksi peluang terjadinya kekeliruan.

Temuan menarik lainnya terkait penerimaan hipotesis pertama adalah semakin bagus gaya berpikir analisis akan membantu untuk mereduksi terjadinya penggunaan informasi yang terbatas untuk membuat keputusan keuangan. Dalam hal ini, responden dalam penelitian ini bertendensi mengargai proses membuat keputusan keuangan yang tepat sehingga tidak hanya melihat hasil akhir dalam membuat keputusan keuangan. Hal ini sangat signifikan mengingat saat ini informasi sangat cepat dan berjumlah banyak sehingga semakin bagus kemampuan analisis maka semakin bagus membuat keputusan keuangan karena keputusan keuangan tersebut dilandasi oleh informasi yang akurat.

Ulasan sebelumnya juga didukung oleh data mentah bahwa mayoritas responden dominan memiliki tipe gaya berpikir analisis sehingga relevan dengan jaman saat ini yakni era informasi yang mana jumlah dan kecepatan informasi untuk berubah sangat intens terjadi 
dan hal ini apabila tidak diimbangi oleh kemampuan melakukan analisis maka dapat menyebabkan kekeliruan dalam mengelola keuangan pribadi dan berefek lanjutan pada tereduksinya peluang mencapai kebebasan keuangan.

Untuk hipotesis kedua, dalam penelitian juga tidak dapat ditolak sehingga semakin tinggi mindset global maka semakin tinggi pula ketepatan seni mengelola kevangan pribadi. Oleh karena itu, ketekunan meningkatkan mindset global menjadi hal yang tak terelakkan. Beberapa temuan menarik dalam penelitian ini diantaranya adalah memiliki mindset global akan memicu kemampuan mencermati informasi pada lingkungan global. Hal ini menjadi kekuatan menimbang bahwa saat ini informasi mampu menembus batas antara negara sehingga kebutuhan untuk mendapatkan informasi yang relevan serta kemampuan menggunakan informasi dari negara lain menjadi kebutuhan juga.

Lanjut bahwa diterimanya hipotesis kedua ini mengindikasikan bahwa perilaku responden dalam penelitian ini tidak bermindset tertutup melainkan terbuka sehingga memudahkan dalam melakukan analisis yang mendalam untuk mengetahui bagaimana keterkaitan suatu peristiwa di negara lain terhadap kondisi keuangan saat ini. Dengan kata lain, mempertajam mindset global akan memudahkan dalam akumulasi kemampuan memahamai berbagai dampak dari peristiwa-peristiwa di negara lain terhadap peluang akumulasi aset keuangan sehingga mampu bersikap dengan tepat ketika ada peristiwaperistiwa yang fiharapkan maupun yang tidak diharapkan.

Selain itu, diterimanya hipotesis kedua menandakan bahwa kemampuan membuat penyimpulan yang tepat terhadap berbagai informasi meningkat peluangnya. Dan hal ini akan mendorong penggunaan informasi yang tepat guna membuat keputusan keuangan. semakin bagus keputusan keuangan maka semakin bagus pula peluang mencapai kebebasan keuangan. Selanjutnya, diterrimanya hipotesis kedua juga menandakan perilaku yang konsisten terhadap anggaran keuangan yang telah dibuat. Maksudnya adalah orang yang memiliki mindset global yang bagus akan mendorong sikap yang tidak mudah menyerah terhadap berbagai stimulus informasi untuk membeli sesuatu. Karena orang yang bermindset global bagus akan lebih baik menyesuaikan diri dengan perunahan lingkungan yang kadang-kadang apabila disikapi secara salah akan membuat keputusan keuangan juga mengalami kesalahan.

Semakin bagus kemampuan untuk menerima perubahan akan mendorong keyakinan positif bahwa ketika membuat keputusan keuangan dibutuhkan toleransi terhadap ketidakpastian. Oleh karena itu, kemampuan menyesuaikan diri yang tercermin dalam perilaku untuk menyesuaikan keputusan keuangan karena adanya perubahan akan mendorong peningkatan seni mengelola keuangan. Semakin bagus mindset global maka semkain bagus pula kecermatan dalam membuat keputusan keuangan dan berefek lanjutan pada akumulasi aset keuangan dibandingkan akumulasi liabilitas keuangan.

Untuk hipotesis terakhir juga sama dengan hipotesis-hipotesis sebelumnya yakni menerima hipotesis alternatif dan menolak hipotesis nol. Dengan kata lain, semakin tinggi manajemen keuangan pribadi (personal finance) maka semkain bagus pula kemampuan memicu intensi berwirasuaha. Akibatnya adalah peluang munculnya enterpreneur baru akan semakin berpeluang meningkat. Alasan diterimannya hipotesis ketiga disebabkan responden yang digunakan dalam penelitian ini dominan berperilaku hemat sehingga kelebihan uang dapat digunakan untuk ditabung. Surplus keuangan itu berpeluang akan memicu intensi berwirausaha sehingga secara langsung menimbulkan benih berwirausaha.

Lanjut bahwa bermodalkan perilaku hemat tersebut mengindikasikan temuan lainnya yakni mampu berpikir kreatif untuk penggunaan uang sehingga memicu ide-ide baru untuk melakukan aktivitas berwirausaha. Apabila benih ini dipertahankan secara berkesinmabungan maka akan memperkuat intensi atau niat berwirausaha. Oleh karena itu, kemampuan mengelola vang yang terindikasi dalam kemampuan mengelola vang sangat 
dibutuhkan untuk meningkatkan niat berwirausaha karena seorang wirausaha membutuhkan ketelitian dalam mengelola uangnya. Dengan kata lain, kemampuan mengelola vang yang tepat akan mendorong niat berwirausaha melalui ketrampilan dan kompetensi mengelola vang seperti menabung dan berinvestasi akan sangat membatu ketika mengelola suatu bisnis. Dan hal ini akan semakin memperkuat niat untuk berwirausaha.

\section{KESIMPULAN}

Niat berwirausaha memainkan peran krusial dalam mereduksi pengangguran dan hal tersbeut tentu saja perlu diupayakan, namun dalam aplikasinya terdapat beberapa faktor yang turut menentukan tinggi rendahnya intensi berwirausaha. Dalam penelitian ini, faktorfaktor yang turut menentukannya adalah gaya berpikir, global mindset dan manajemen keuangan pribadi. Menurut hasil analisis, semua hipotesis diterima sehingga semua faktor tersebut signifikan berpengaruh untuk memicu intensi berwirausaha. Oleh karena itu, perlu upaya yang terencana untuk meningkatkan ketiga faktor tersebut secara berkeninambungan. Selain dari pada itu, dalam penelitian ini juga terdapat beberapa kelemahan yang dapat diperbaiki pada penelitian mendatang yaitu belum menggunakan responden yang terlibat langsung dalam aktivitas berwirausaha. Oleh karena itu, pada penelitian mendatang sebaiknya menggunakan responden yang merupakan para enterpreneur.

\section{DAFTAR REFERENSI}

Allison, C. W. and Hayes, J. 1996. The Cognitive Style Index: A Measure Of Intuition Analysis For Organizational Research. Joumat qf Management Studies 33:1 January $19960022-$ 2380, pp. 119-135

Beamish, P. W, Killing, J. P, Lecraw, D. J. \& Morrison, A. J. 1994. Intaxatiunal Management: Text and Cases. Irwin, Boston.

Ghozali, I. 2001. Aplikasi Analisis Multivariat Dengan Program SPSS, Badan Penerbitan UNDIP, Semarang

Gupta, A. K., Govindarajan, V. 2002. Cultivating a global mindset. Academy of Management Executive, 16 (1), 116-126.

Hartono, A. 2007. Developing a Global Mindset: Individual and Organizational Level. Jurnal Eksekutif, Volume 4, Nomor 3, Desember

Indira, C. K. and Soenhadji, I. M. 2010. Students Enterpreneurships Intention: Study Of Comparison Between Java And Non Java. Jurusan Manajemen, fakultas Ekonomi Universitas Gunadarma (2010) 10206196 - http://www.gunadarma.ac.id

Indarti, N. and Rostiani, R. 2010. Intensi Kewirausahaan Mahasiswa: Studi Perbandingan Antara Indonesia, Jepang dan Norwegia. Jurnal Ekonomika dan Bisnis Indonesia, Vol. 23, No. 4, Oktober 2008

Institute for Socio-Financial Studies (2000). Personal Finance and the Rush to Competence: Financial Literacy Education in the U.S. A National Field Study Commissioned and Supported by The Fannie Mae Foundation

Kahneman, D. 2003. Maps of Bounded Rationality: Psychology for Behavioral Economics. The American Economic Review, 93(5), pp. 1449-1475, December 2003

Kawulur, A. F. 2009. Pelatihan Tentang Pengelolaan Keuangan Terhadap Penghasilan Nelayan Di Desa Likupang Dua Kecamatan Likupang Timur. Abdimas Vol,2 No.4 Desember 2009

Kerkmann, B. C. 1998. Motivation And Stages Of Change In Financial Counseling: An Application Of A Transtheoretical Model From Counseling Psychology. Financial Counseling and Planning, Volume 9(1), 1998

Kotzè, L. \& Smit, A. V. A. 2008. Personal finances: What is the possible impact on entrepreneurial activity in South Africa? Southern African Business Review Volume 12 Number 32008 
Krishna, A, Rofaida, R. and Sari, M. 2010. Analisis tingkat literasi keuangan di kalangan mahasiswa dan faktor-faktor yang mempengaruhinya (Survey pada Mahasiswa Universitas Pendidikan Indonesia). Proceedings of The 4th International Conference on Teacher Education; Join Conference UPI \& UPSI Bandung, Indonesia, 8-10 November 2010

Nasution, D. and Supriyadi. 2007. Pengaruh Urutan Bukti, Gaya Kognitif, Dan Personalitas Terhadap Proses Revisi Keyakinan. Simposium Nasional Akuntansi X AMKP-07

Nofsinger, J. R. \& Varma, A. 2007. How analytical is your financial advisor?. Financial Services Review 16 (2007) 245-260

Oseifuah, E. 2010. Financial Literacy and Youth Entrepreneurship in Vhembe District, Limpopo Province. African Journal of Economic and Management Studies, Vol. 1 Iss: 2, pp. 164 $-182$

Parrota, J. L. \& Johnson, P. J. 1998. The Impact Of Financial Attitudes And Knowledge On Financial Management And Satisfaction Of Recently Married Individuals. Association for Financial Counseling and Planning Education

Paul, H. 2000. Creating a Mindset. Thunderbird International Business Review, 42(2): 187-200

Paul, K, Meyskens, M. \& Robbins, S. Components of a global mindset: corporate social responsibility and cross-cultural sensitivity. Journal of International Business and Cultural Studies

Prochaska, K, Cue .1993. An Exploratory Study for a Model of Personal Financial Management Style. Financial Counseling and Planning, Volume 4, 1993

Rettig, K. D. \& Schulz, C. L. 1991. Cognitive Style Preferences and Financial Management Decision Styles. Financial Counseling and Planning, Volume 2, 1991

Sarwoko, E. 2011 . Kajian Empiris Entrepreneur Intention Mahasiswa. JURNAL EKONOMI BISNIS, TH. 16, NO. 2, JULI 2011

Sina, P. G. \& Ida. 2012. Financial Literacy And Cognitive Style On Entrepreneurial Intentions. Global Network Journal - Vol. 5 No. 2 August 2012

Supramono \& Utami, I. 2004. Desain Proposal Penelitian, Andi Offset, Yogyakarta

Wijaya, T. 2007. Hubungan Adversity Intelligence dengan Intensi Berwirausaha (Studi Empiris pada Siswa SMKN 7 Yogyakarta). JURNAL MANAJEMEN DAN KEWIRAUSAHAAN, VOI.9, No. 2, September 2007: 117-127

Yende, N. P. 2010. The Key Global Mindset Factors Affecting Competitiveness Performance of South African Soft Drinks Companies. University of Pretoria 